\title{
Perdagangan Saham di Pasar Modal Perspektif Hukum Ekonomi Syariah (Studi Transaksi di Pasar Perdana dan Pasar Sekunder Pada Pasar Modal)
}

\author{
Nahara Eriyanti \\ UIN Ar-Raniry Banda Aceh \\ nahara.eriyanti@ar-raniry.ac.id
}

\begin{abstract}
Basically a limited liability company (PT) has various alternative funding sources, both from within and outside. Alternative funding from within the PT generally uses profits retained by $P T$. While alternative funding from outside $P T$ can come from creditors in the form of debt, issuance of debt securities such as bonds, and issuance of participatory letters, namely shares by selling shares known as going public. Then the focus of this research is the form of stock trading transactions, especially the buying and selling of shares on the stock exchange or the capital market. The purpose of this study is to analyze how the Islamic economic law review of the mechanism of stock trading in the capital market both in the primary and secondary markets. This type of research uses library research with descriptive-analytical analysis methods. The results showed that the stock trading transaction on the stock exchange or capital market had fulfilled the provisions in Islamic law. In the primary market, both the initial share price and share price offered when going public offered by the issuer have been agreed by investors, which is in accordance with the principles of bermuamalat which is the principle of willingness (antarodhin) which shows the agreement of the two parties in the transaction. Furthermore, in the secondary market, transaction mechanisms are permitted in Islamic law, because they are categorized in the sale and purchase of greetings, related to fluctuating prices because they originate from supply and demand, profit-seeking activities such as capital gains are permitted by sharak, because they are things that are reasonable because basically in business is the pursuit of profit.
\end{abstract}

Keywords: stock, go public, capital market

\begin{abstract}
Abstrak
Pada dasarnya perseroan terbatas (PT) mempunyai berbagai alternatif sumber pendanaan, baik yang berasal dari dalam maupun luar. Alternatif pendanaan dari dalam PT umumnya dengan menggunakan laba yang ditahan oleh PT. Sedangkan alternatif pendanaan dari luar PT dapat berasal dari kreditur berupa hutang, penerbitan surat-surat hutang seperti obligasi, dan penerbitan surat bersifat penyertaan yaitu saham dengan melakukan penjualan saham yang dikenal dengan go public. Kemudian yang menjadi fokus penelitian ini adalah bentuk transaksi perdagangan saham, khususnya jual beli saham di bursa efek atau pasar modal. Tujuan dari penelitian ini adalah untuk menganalisa bagaimana tinjauan hukum ekonomi syariah terhadap mekanisme perdagangan saham di pasar moda baik di pasar perdana maupun pasar sekunder. Jenis penelitian ini menggunakan library research dengan metode analisa deskriptifanalitis. Hasil penelitian menunjukkan bahwa kegiatan transaksi perdagangan saham di bursa efek atau pasar modal sudah memenuhi ketentuan-ketentuan
\end{abstract}


dalam hukum Islam. Dalam pasar perdana, harga saham perdana maupun agio saham yang ditawarkan ketika go public yang ditawarkan oleh emiten sudah disepakati oleh investor, yang mana sesuai dengan prinsip-prinsip dalam bermuamalat yaitu prinsip kerelaan (an-tarodhin) yang menunjukan kesepakatan kedua belah pihak yang bertransaksi. Selanjutnya dalam pasar sekunder, mekanisme transaksi diperbolehkan dalam hukum Islam, karena dikategorikan dalam jual beli salam, berkaitan dengan harga yang berfluktuasi karena berasal dari permintaan dan penawaran (supply and demand), kegiatan mengejar keuntungan seperti capital gain diperbolehkan oleh syarak, karena merupakan hal yang wajar karena pada dasarnya dalam berbisnis adalah mengejar keuntungan.

Kata Kunci: saham, go public, pasar modal

\section{PENDAHULUAN}

Dalam perkembangan dunia bisnis yang semakin kompleks, transaksi jual beli saham adalah merupakan hal yang biasa, yang mana sebagai sesuatu yang terjadi karena adanya tuntutan kebutuhan manusia dalam menghadapi tantangan zaman khususnya dalam bidang ekonomi.

Perusahaan-perusahaan yang sudah terbentuk seperti perseroan terbatas (PT), seringkali tidak berkembang maksimal. Hal ini banyak disebabkan oleh tidak adanya kontrol keuangan baik untuk pemasukan maupun pengeluaran, di samping kurangnya kemampuan dalam manajemen atau pengelolaan PT.

Pada dasarnya PT mempunyai berbagai alternatif sumber pendanaan, baik yang berasal dari dalam maupun luar. Alternatif pendanaan dari dalam PT umumnya dengan menggunakan laba yang ditahan oleh PT. Sedangkan alternatif pendanaan dari luar PT dapat berasal dari kreditur berupa hutang, penerbitan surat-surat hutang seperti obligasi, dan penerbitan surat bersifat penyertaan yaitu saham dengan melakukan penjualan saham yang dikenal dengan go public.

Go public merupakan kegiatan penawaran umum atas saham yang dilakukan oleh emiten (PT) kepada seluruh masyarakat sesuai dengan mekanisme dan tata cara yang diatur oleh UU Pasar Modal. Go public menjadi salah satu alternatif untuk memecahkan segala permasalahan di atas. Di samping modal yang dibutuhkan akan cepat tersedia dan pengelolaan lebih professional lagi, dengan go public juga segala sesuatu yang berhubungan dengan jalannya PT akan dapat dikontrol lebih cepat dan luasnya ekspos atau publikasi perusahaan kepada masyarakat melalui bursa lebih terbuka. Berikut keuntungan bagi perusahaan melakukan penawaran umum atau go public:

1. Perusahaan menginginkan potensi untuk mendapatkan tambahan modal daripada harus melalui kredit pembiayaan (debt financing);

2. Peningkatan likuiditas perusahaan terhadap kepentingan pemegang saham utama dan pemegang saham minoritas; 
Perdagangan Saham di Pasar Modal Perspektif Hukum Ekonomi Syariah (Studi Transaksi di Pasar Perdana dan Pasar Sekunder Pada Pasar Modal)

3. Dapat melakukan penawaran saham atau efek di pasar sekunder;

4. Meningkatkan prestise dan publisistas perusahaan;

5. Kemampuan untuk mengadopsi karyawan dengan menawarkan opsi (option) (Nasarudin dkk, 2014).

Meskipun demikian, ada beberapa kelemahan dalam penawaran umum atau go public, yaitu:

1. Adanya tambahan biaya untuk mendaftarkan efek pada penawaran umum;

2. Meningkatnya pengeluaran dan pemaparan potensi kewajiban berkenaan dengan regristasi dan laporan berkala;

3. Hilangnya kontrol terhadap persoalan manajemen, karena terjadi dilusi kepemilikan saham;

4. Keharusan untuk mengumumkan besarnya pendapatan perusahaan dan pembagian dividen;

5. Efek yang diterbitkan mungkin saja tidak terserap oleh masyarakat sesuai dengan perhitungan perusahaan (Nasarudin dkk, 2014: 216).

Go public dalam pelaksanaannya terbagi menjadi dua tahap, yaitu transaksi di pasar perdana dan transaksi di pasar sekunder. Transaksi perdagangan saham, khususnya jual beli saham di bursa efek atau pasar modal termasuk dalam ruang lingkup muamalat. Bidang muamalat mempunyai aturan-aturan yang sangat fleksibel yaitu bahwa semua bentuk muamalat diperbolehkan selama cara dan prinsip-prinsipnya sesuai dengan ajaran Islam. Menurut pandangan Mustafa az-Zarqa sebagaimana dikutip oleh Yusdani menejelaskan bahwa manusia dianjurkan untuk membuat bentuk dan macam-macam akad atau transaksi baru, yang mana sesuai dengan kebutuhan dan perkembangan kehidupan muamalat di antara manusia, selama transaksi-transaksi tersebut sesuai dengan prinsip-prinsip syari'ah (Yusdani, 2002). Sebagaimana dalam firman-Nya:

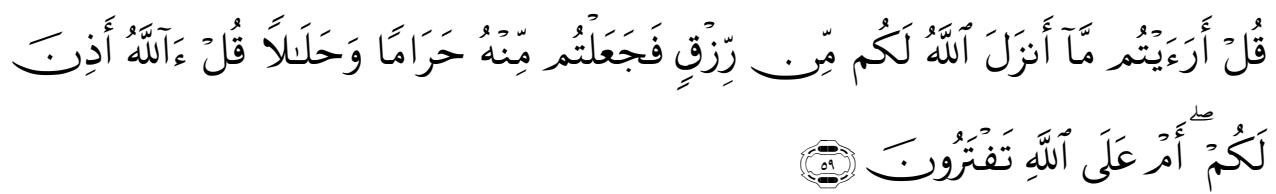

Artinya:

Katakanlah: "Terangkanlah kepadaku tentang rezki yang diturunkan Allah kepadamu, lalu kamu jadikan sebagiannya haram dan (sebagiannya) halal". Katakanlah: "Apakah Allah Telah memberikan izin kepadamu (tentang ini) atau kamu mengada-adakan saja terhadap Allah ?"

Dari ayat tersebut, mempunyai makna bahwa Allah telah memberikan izin atau keleluasaan pada manusia untuk mengerjakan 
sesuatu di luar yang telah digariskan haram oleh syari'ah atau hukum Islam. Hal tersebut juga dikuatkan oleh adanya kaidah fikih yang dirumuskah oleh para fukaha yang bunyinya sebagai berikut:

$$
\text { الآصل فى لاشياء الاباحة حتّى يدلّ الدّليل على تحريمه }
$$

Artinya:

"Pada dasarnya segala transaksi (mu'amalat) itu diperbolehkan kecuali ada dalil yang mengharamkan"

Kaidah fikih tersebut, apabila ditelusuri mempunyai suatu makna bahwa bidang muamalat dan pembahasannya yang belum terdapat pada nash-nash seperti al-Qur'an dan as-Sunnah, maka hal itu bukan berarti dilarang atau tidak diperbolehkan oleh syarak. Namun, selama transaksitransaksi yang dilakukan itu sesuai dengan apa yang telah digariskan oleh syarak, maka hal itu menjadi mubah (boleh) selama tidak ada dalil atau nash yang mengharamkannya.

Berangkat dari berbagai pemaparan di atas, penyusun akan membahas secara detail mengenai transaksi perdagangan efek di pasar perdana dan pasar sekunder pada pada pasar modal atau bursa efek dengan mengacu pada hukum positif maupun dari aspek hukum Islam.

\section{PEMBAHASAN}

\section{A. Transaksi di Pasar Perdana}

Dalam perdagangan efek di pasar perdana, dalam hal ini prinsip mubah dapat diterapkan. Dalam transaksi tersebut telah mampu mengakomodir prinsip-prinsip mu'amalat yang lainnya yaitu adanya sikap sukarela atau suka sama suka (an-tarodhin), mendahulukan maslahat daripada madharat dan adanya keadilan dalam transaksi.

Mekanisme transaksi jual beli saham perseroan terbatas (PT) yang terjadi di pasar perdana bahwa perjanjian yang diadakan antara investor dan underwriter yang disahkan serta ditandatangani oleh masing-masing pihak yang menyatakan persetujuannya merupakan suatu ijab yang berarti setuju. Sementara itu, penerimaan oleh investor dengan secara nyata dan jelas berarti kabul.

Harga saham di pasar perdana bersifat tetap dan penentuannya berdasarkan kesepakatan antara PT dengan penjamin emisi (underwriter). Oleh karena itu agio saham yang diperoleh di pasar perdana bukanlah termasuk riba, karena keuntungan yang diperoleh merupakan harga saham yang telah disepakati oleh penerbit saham dan underwriter. Penerbit saham atau PT mempunyai hak atas agio saham tersebut untuk dimanfaatkan demi kesejahteraan anggota-anggotanya, sedangkan bagi investor bahwa agio saham yang tinggi berarti ia mempunyai hak untuk 
Perdagangan Saham di Pasar Modal Perspektif Hukum Ekonomi Syariah (Studi Transaksi di Pasar Perdana dan Pasar Sekunder Pada Pasar Modal)

menikmati laba di kemudian hari, sehingga memberikan kesejahteraan yang lebih besar. Di samping itu juga, proses penjualan saham antara investor yang diwakili agen penjual dengan underwriter diawali dengan pengisian formulir yang akhirnya ditandatangani oleh masing-masing pihak.

Suatu transaksi dalam bisnis terutama transaksi perdagangan saham di bursa efek dapat dilakukan, selama hubungan itu mendatangkan kebaikan dan manfaat (kemaslahatn) bagi kehidupan serta tidak menimbulkan kemadharatan bagi kedua belah pihak yang bertransaksi. Transaksi jual beli saham PT di pasar perdana, mempunyai manfaat dan kemaslahatan bagi berbagai pihak selain kedua belah pihak yang bertransaksi yaitu bagi investor, emiten maupun pemerintah sendiri.

Kemaslahatan bagi investor, antara lain dapat dilihat bahwa investor dapat memperoleh dividen, mempunyai hak suara dalam Rapat Umum Pemegang Saham (RUPS), dapat dengan mudah mengganti instrument investasi, misal dari saham A ke saham B sehingga dapat meningkatkan keuntungan atau mengurangi risiko. Di samping itu juga dapat sekaligus melakukan investasi dalam beberapa instrumen yang ada di perseroan terbatas (PT).

Adapun kemaslahatan bagi perseroan terbatas (PT) yang menerbitkan saham atau biasa yang disebut dengan emiten adalah bahwa PT dapat memperoleh sejumlah dana yang besar dan sekaligus dapat langsung diterima pada saat pasar perdana selesai, ketergantungan PT terhadap bank yang biasanya mengajukan pembiayaan akan menjadi kecil, dan yang terpenting adalah bahwa PT kecil dan menengah dapat mengembangkan perusahaannya, bahkan dengan adanya go public tersebut PT akan semakin terekspos dan terpublikasi yang akan dikenal oleh masyarakat secara luas.

Di samping itu bagi pemerintah, bahwa dengan adanya transaksi perdagangan saham di bursa efek yaitu sejalan dengan tujuan pemerintah untuk pemerataan hasil pembangunan, membuka lapangan pekerjaan yang lebih luas, terlebih dengan era tahun sekarang di 2015 sudah ada yaitu Masyarakat Ekonomi Asean (MEA) yang mana emiten, investor, pemerintah maupun kalangan lainnya dituntut dalam kesetaraan di bidang ekonomi dan tidak kalah pentingnya adalah untuk mengurangi ketegangan sosial di berbagai kalangan masyarakat.

Dengan demikian, berdasarkan indikasi-indikasi dari kemaslahatan yang diperoleh masing-masing pihak bahwa prinsip-prinsip syari'ah yang mendatangkan maslahat dan menolak madharat sudah terangkum dan terlaksana dalam proses transaksi jual beli saham di bursa efek atau pasar modal.

Adanya pendistribusian prospektus dalam pasar perdana, yang mana memuat segala segala sesuatu yang berkaitan dengan PT dan ditulis 
secara komprehensif dan akurat itu adalah untuk menyeimbangkan di antara masing-masing pihak yang saling memiliki hak. Investor, sebelum memutuskan untuk memilih saham PT, berhak untuk terlebih dahulu tahu akan kualitas dan kredibilitas PT tersebut, sehingga salah satu pihak tidak ada yang merasa dirugikan.

Dengan adanya prospektus tersebut, seorang investor akan memilih untuk tertarik atau tidak untuk membeli saham suatu PT. Oleh karena itu, prinsip full disclosure (keharusan keterbukaan informasi) sangat diperlukan supaya pihak investor tidak merasa dirugikan dan terhindar dari penyelewengan dan penipuan. Sehingga, keseimbangan untuk saling memiliki hak di antara masing-masing pihak akan terwujud (Budi Untung, 2011).

Adanya dokumen-dokumen dalam jual beli seperti surat-surat perjanjian dalam bentuk formulir, atau kuitansi dan akta-akta yang lainnya adalah untuk mencegah adanya penipuan, kerugian salah satu pihak dan pertengkaran. Adanya dokumen-dokumen tersebut adalah sebagai bukti hitam di atas putih yang mengingatkan para pihak ketika berselisih atau khilaf, ragu-ragu atau bahkan lupa (Hamzah, 1999).

\section{B. Transaksi di Pasar Sekunder}

Ada beberapa hal yang membedakan antara pasar perdana dan pasar sekunder yaitu, dalam pasar perdana terjadi hanya penjualan saja, yang mana emiten (PT) mengeluarkan emisi baru atau saham (efek). Sementara di pasar sekunder, dapat terjadi penjualan dan pembelian pada setiap harinya.

Dapat diketahui bahwa harga saham di pasar sekunder tidak lagi ditentukan oleh kesepakatan antara PT dan underwriter sebagaimana yang terdapat pada pasar perdana. Melainkan harga saham yang ditentukan berdasarkan teori penawaran dan permintaan (supply and demand). Di samping itu juga ditentukan oleh prospektus PT yang menerbitkan saham tersebut. Oleh karena itu, harga saham di pasar sekunder bias saja lebih tinggi daripada di pasar perdana. Hal demikian terjadi apabila saham mengalami kelebihan permintaan atau kerana saham itu banyak diminati oleh publik, di samping itu prospek perusahaan cukup bagus. Selain itu, bias saja harga saham terjadi sebaliknya, di mana kelebihan penawaran yang cenderung turun.

Dari harga saham yang berfluktuasi di pasar sekunder adalah hal yang wajar dan mubah (boleh), karena adanya permintaan dan penawaran (supply and demand). Yang terpenting adalah saham-saham yang diperjualbelikan itu bidang usahanya tidak bertentangan dengan syari'ah. Melihat fluktuasi harga saham yang begitu cepat, Marzuki Usman mengatakan bahwa saham itu adalah sesuatu yang bersifat abstrak dan pasarnya bersifat terbuka ke seluruh dunia. 
Perdagangan Saham di Pasar Modal Perspektif Hukum Ekonomi Syariah (Studi Transaksi di Pasar Perdana dan Pasar Sekunder Pada Pasar Modal)

Ketika investor membeli saham, diawali dengan mengisi formulir yang dianggap sebagai suatu pesanan, dan ketika sudah penjatahan saham kemudian membayarnya. Setelah pembayaran tersebut, investor dan agen penjual (broker) sama-sama sepakat bahwa penyerahan barang (surat saham) dilakukan pada hari keempat setelah transaksi $(\mathrm{T}+4)$. Proses transaksi tersebut melalui pemesanan dan pembayaran terlebih dahulu, dalam pandangan hukum Islam disebut dengan jual beli salam. Salam dalam fikih muamalat adalah suatu bentuk jual beli barang dengan ketentuan si pembeli membayar saat itu untuk barang yang akan diterimanya masa mendatang (Shiddiqi, 1996). Dalam arti, pembayaran terlebih dahulu sedangkan penyerahan barang dilakukan kemudian.

Dalam transaksi jual beli salam harus jelas kuantitas, kualitas dan waktu penyerahannya. Para ulama sudah sepakat bahwa salam dibenarkan dalam syarak baik al-Qur'an maupun as-Sunnah. Bahkan menurut penegasan oleh Ibnu Munzir sebagaimana dikutip oleh Hamzah Ya'qub menyebutkan bahwa telah diperhatikan dari segenap ahli ilmu, dan mereka sama-sama menerangkan bahwa salam itu boleh (Hamzah Yqub, 232).

Berdasarkan hal tersebut, bahwa jual beli saham di pasar sekunder termasuk jual beli salam. Karena dalam jual beli saham tersebut dilakukan dengan cara-cara yang telah disepakati, baik kuantitas maupun kualitas maupun waktu penyerahannya. Dengan demikian, proses jual beli saham di pasar sekunder tersebut sangat menjunjung tinggi nilai-nilai atau prinsip-prinsip muamalat.

Adapun mengenai capital gain (selisih antara harga jual dan harga beli), selalu berubah-ubah karena mengalami fluktuasi harga, diburu oleh para investor untuk mendapatkan laba atau keuntungan yang lebih besar. Kegiatan memburu capital gain di pasar sekunder adalah suatu hal yang wajar, karena pada dasarnya dalam berbisnis berorientasi kepada laba atau keuntungan.

Keberadaan agen dalam jual beli saham (broker atau pialang), dalam hukum Islam dinamakan dengan wakalah (wakil) yang mana didefinisikan sebagai permohonan seseorang kepada orang lain untuk menggantikan dirinya dalam suatu urusan yang boleh digantikan seperti menjual, membeli, dan lain sebagainya (Abu Bakr, 1976).

Dalam proses penyelesaian transaksi saham menggunakan komputer. Di Bursa Efek Jakarta (BEJ), kegiatan ini dikenal dengan istilah JATS (Jakarta Automated Trading System) (Hulwati, 2001). Hal tersebut tidak menjadi persoalan, karena sistem perdagangan ini telah dicatat menggunakan alat elektronik yaitu komputer. Hal tersebut sesuai dengan firman-Nya: 


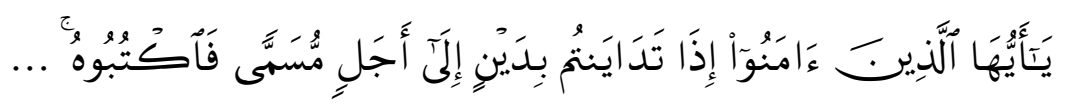

Artinya:

"Hai orang-orang yang beriman, apabila kamu bermu'amalah tidak secara tunai untuk waktu yang ditentukan, hendaklah kamu menuliskannya..."

Dalam ayat tersebut, dalam setiap transaksi adalah suatu keharusan untuk mencatatnya untuk mencegah adanya tindakan penipuan yang menimbulkan kerugian oleh salah satu pihak yang akan berujung pada konflik atau sengketa. Pencatatan dalam setiap transaksi perdagangan saham di bursa efek atau pasar modal tersebut yang mana menggunakan sistem elektronik diperbolehkan karena sudah sesuai dengan ketentuan-ketentuan syari'ah. Seperti diketahui bahwa dunia modern saat ini hukum berkembang mengikuti perubahan tempat dan zaman, untuk itu segala ketentuan-ketentuan yang ada dalam dunia fikih klasik adanya keharusan untuk berkembang dan tidak mandeg sehingga dapat diaktualisasikan dalam berbagai persoalan kontemporer atau kekinian khususnya dalam bidang muamalat

Dalam hukum positif sebagai payung hukum transaksi perdagangan saham di pasar modal sebagaimana yang diatur dalam Undang-Undang Nomor 8 Tahun 1995 Tentang Pasar Modal. Berkenaan dengan hal itu, pemerintah dengan DSN-MUI berlanjut membuat Nota Kesepahaman dengan pembentukan pasar modal yang berdasarkan prinsip-prinsip syari'ah. Upaya tersebut dilanjutkan dengan keluarnya Fatwa DSN-MUI Nomor 20/DSN-MUI/IV/2001 tentang Pedoman Investasi untuk Reksadana Syariah.

\section{KESIMPULAN}

Dari berbagai uraian di atas dapat disimpulkan bahwa kegiatan transaksi perdagangan saham di bursa efek atau pasar modal sudah memenuhi ketentuan-ketentuan dalam hukum Islam. Dalam pasar perdana, harga saham perdana maupun agio saham yang ditawarkan ketika go public yang ditawarkan oleh emiten sudah disepakati oleh investor, yang mana sesuai dengan prinsip-prinsip dalam bermuamalat yaitu prinsip kerelaan (an-tarodhin) yang menunjukan kesepakatan kedua belah pihak yang bertransaksi.

Dalam pasar sekunder mekanisme transaksi diperbolehkan dalam hukum Islam, karena dikategorikan dalam jual beli salam, berkaitan dengan harga yang berfluktuasi karena berasal dari permintaan dan penawaran (supply and demand), kegiatan mengejar keuntungan seperti capital gain diperbolehkan oleh syarak, karena merupakan hal yang wajar 
Perdagangan Saham di Pasar Modal Perspektif Hukum Ekonomi Syariah (Studi Transaksi di Pasar Perdana dan Pasar Sekunder Pada Pasar Modal)

karena pada dasarnya dalam berbisnis adalah mengejar keuntungan, sedangkan untuk agen atau broker dalam konsep fikih dikenal dengan wakalah, dan untuk penyelesaian transaksi dicatat dalam sistem bursa elektronik yang menggunakan sistem komputer yang mana juga sudah sesuai dengan al-Qur'an yaitu QS. al-Baqarah ayat 282. 


\section{DAFTAR PUSTAKA}

Al-Jazairi, Abu Bakr Jabir, Minhaj al-Muslim, cet. ke-8, Beirut: Dar al-Fikr, 1976.

As-Suyuti, Jalaluddin Abdurrahman Ibnu Abu Bakr, al-Asybah wa anNaza'ir, Beirut: Dar al-Fikr, t.t.

Departemen Agama RI, Al-Qur'an dan Terjemahannya, 30 Juz, Cet. ke-10, Jakarta: Darus Sunnah, 2002.

Hulwati, Transaksi Saham di Pasar Modal Indonesia Perspektif Hukum Ekonomi Islam, cet. ke-1, Yogyakarta: UII Press, 2001.

M. Irsan Nasarudin dkk., Aspek Hukum Pasar Modal, cet. ke-7, Jakarta: Kencana Prenada Media Group, 2011.

Siddiqi, M. Nejatullah, Kemitraan Usaha dan Bagi Hasil dalam Hukum Islam, alih bahasa Fakhriyyah Mumtihani, cet. ke-1, Jakarta: Dana Bhakti Prima Yasa, 1996.

Ya'qub, Hamzah, Kode Etik Dagang Menurut Islam, cet. ke-2, Bandung: Diponegoro, 1999.

Yusdani, "Transaksi (Akad) dalam Perspektif Hukum Islam”, Millah, vol. II, no.2, 2002. 